\title{
ОСОБЛИВОСТІ ОРГАНІЗАЦІЇ ОСОБИСТІСНОГО ПРОСТОРУ ВІЙСЬКОВОСЛУЖБОВЦІВ 3 ОЗНАКАМИ ПТСР
}

\section{Коширець Віктор}

Волинський національний університет імені Лесі Українки,

м. Луцьк, Україна, https://orcid.org/0000-0002-4790-8839, victorkoshirets@gmail.com

\section{Шкарлатюк Катерина}

Волинський національний університет імені Лесі Українки, м. Луцьк, Україна, shkarlatiuk2012@ukr.net

Mema. У статті розглянуто особливості організації особистісного простору військовослужбовців 3 ознаками посттравматичного стресового розладу. Визначено основні напрями та підходи до дослідження поняття психологічного простору, а також впливу психотравмувальних подій на організацію особистісного простору як компонента структури життєвого простору. Здійснено теоретичне обгрунтування поняття особистісного простору військових й емпірично досліджено його психологічні особливості.

Memoдu. Використано стандартизовані психодіагностичні методики «Суверенність психологічного простору» С. К. Нартова-Бочавер, опитувальник пацієнта про стан здоров'я Patient Health Questionnaire (PHQ) -9, опитувальник для скринінгу посттравматичного стресового розладу, шкала оцінки впливу травматичної подіï Impact of Event Scale (IES-R).

Результати. Виявлено, що рівень суверенності простору, тіла, соціальних зв'язків, речей, цінностей пов'язаний із появою ознак ПТСР у військовослужбовців. Проведене дослідження дає підстави констатувати у військовослужбовців з ознаками ПТСР психологічні особливості, які негативно впливають на їхнє повсякденне життя, процеси адаптації, ресоціалізації та організацію їхнього особистісного простору. Низький рівень суверенності психологічного простору засвідчує ознаки депривації, яка проявляється в переживанні підпорядкованості, відчуженості, фрагментарності власного життя й характеризується труднощами в пошуку об'єктів середовища, із якими люди себе ідентифікують.

Висновки. Дослідження показало, що у військових із низьким рівнем суверенності психологічного простору яскраво виражені показники схильності до посттравматичного стресового розладу. Тобто низька суверенність простору, тіла, соціальних зв'язків, речей, цінностей впливає на вірогідність виникнення у військовослужбовців ознак ПТСР. Аналогічний взаємозв'язок виявлено між рівнем суверенності й наявністю тенденції до ПТСР: ті військовослужбовці, які

ISSN 2308-3743 (Online), ISSN 2227-1376 (Print)

(C) Коширець В., Шкарлатюк К., 2020. Ця стаття відкритого доступу на умовах CC BY-NC 4.0 
мають високий рівень суверенності психологічного простору, не мають виражених ознак посттравматичного стресового розладу. Продемонстровано важливість виконання завдань реабілітації, ранньої діагностики та психокорекції військових із метою забезпечення їхнього психічного здоров’я, а також для розвитку особистісної й професійної самореалізації.

Ключові слова: особистісний простір, суверенність психологічного простору, військовослужбовці, травматична подія, ПТСР, психічне здоров’я.

Koshyrets Victor, Shkarlatyuk Kateryna. Peculiarities of Personality Space Organization of Servicemen with PTSD Signs. The Aim. The article deals with the peculiarities of personality space organization of servicemen with posttraumatic stress disorder signs. The main directions and approaches to the study of the psychological space concept as well as the impact of traumatic events on personality space organization as a component of a living space structure are identified. Theoretical grounding of the concept of personality space of servicemen is carried out and its psychological peculiarities are empirically studied.

The Methods. The standardized psychodiagnostic methods «Sovereignty of psychological space» by Nartova-Bochaver, the Patient Health Questionnaire (PHQ)-9, the posttraumatic stress disorders screening questionnaire (PTSD SQ), the Impact of Event Scale-Revised (IES-R) are used.

The Results. It has been determined that sovereignty levels of space, body, social relations, things, and values are associated with the appearance of PTSD signs among servicemen. The conducted research allows to ascertain psychological features among servicemen with PTSD signs that negatively affect their daily lives, the processes of adaptation, resocialization, and organization of their personalality space. The low level of psychological space sovereignty shows signs of deprivation, which is manifested in the experience of subordination, alienation, fragmentation of own life and is characterized by difficulties in finding environment objects with which people identify themselves.

The Conclusions. The research showed that indicators of predisposition to posttraumatic stress disorder are clearly expressed among servicemen with the low level of psychological space sovereignty. That is, the low sovereignty of space, body, social connections, things, and values affects the probability of PTSD signs occurrence among servicemen. The similar relationship is found out between the level of sovereignty and the tendency presence to PTSD: those servicemen who have high level of psychological space sovereignty do not have the pronounced signs of posttraumatic stress disorder. The importance of solving the rehabilitation tasks, early diagnoses and psychocorrection of servicemen to ensure their mental health, as well as for the development of their personality and professional self-realization is demonstrated.

Key words: personality space, psychological space sovereignty, servicemen, traumatic event, PTSD, mental health.

Коширец Виктор, Шкарлатюк Екатерина. Особенности организации личностного пространства военнослужащих с признаками ПТСР. Цель. В 
статье рассматриваются особенности организации личностного пространства военнослужащих с признаками посттравматического стрессового расстройства. Определяются основные направления и подходы к исследованию понятия психологического пространства, а также влияния психотравмирующих событий на организацию личностного пространства как компонента структуры жизненного пространства. Осуществляется теоретическое обоснование понятия личностного пространства военных и эмпирически исследуются его психологические особенности.

Memoдbl. Используются стандартизированные психодиагностические методики «Суверенность психологического пространства» С. К. НартоваБочавер, опросник пациента о состоянии здоровья Patient Health Questionnaire (PHQ)-9, опросник для скрининга посттравматического стрессового расстройства, шкала оценки влияния травматического события Impact of Event Scale (IES-R).

Pезультаты. Оказалось, что уровень суверенности пространства, тела, социальных связей, вещей, ценностей связан с появлением признаков ПТСР у военнослужащих. Проведенное исследование позволяет констатировать у военнослужащих с признаками ПТСР психологические особенности, которые негативно влияют на их повседневную жизнь, процессы адаптации, ресоциализации и организацию их личностного пространства. Низкий уровень суверенности психологического пространства свидетельствует о признаках депривации, которая проявляется в переживании подчиненности, отчужденности, фрагментарности собственной жизни и характеризуется трудностями в поиске объектов среды, с которыми люди себя идентифицируют.

Вывюды. Исследование показало, что у военных с низким уровнем суверенности психологического пространства ярко выражены показатели склонности к посттравматическому стрессовому расстройству. Таким образом, низкая суверенность пространства, тела, социальных связей, вещей, ценностей влияет на вероятность возникновения у военнослужащих признаков ПТСР. Аналогичная взаимосвязь обнаружена между уровнем суверенности и наличием тенденции к ПТСР: те военнослужащие, которые имеют высокий уровень суверенности психологического пространства, не имеют выраженных признаков посттравматического стрессового расстройства. Продемонстрирована важность решения задач реабилитации, ранней диагностики и психокоррекции военных с целью обеспечения их психического здоровья, а также для развития личностной и профессиональной самореализации.

Ключевые слова: личностное пространство, суверенность психологического пространства, военнослужащие, травматическое событие, ПТСР, психическое здоровье.

Постановка наукової проблеми та іï значення. Дослідження особистісного простору військовослужбовців - це актуальний напрям вивчення в психології в сучасних умовах життя, для України, зокрема, коли є великий інтерес до військової справи та осіб, які виконують свій військовий обов'язок. Проте недостатньо вивчено аспекти цієї 
проблематики, що стосуються питання організації особистісного простору військових, котрі мають ознаки посттравматичного стресового розладу. Саме це набуває особливого значення в контексті системних і диференціально-психологічних досліджень. Участь у бойових діях впливає на свідомість людини, піддаючи ііі серйозним якісним змінам. Посттравматичні стресові порушення сприяють формуванню специфічних сімейних взаємин, особливих життєвих сценаріїв і можуть впливати на все подальше життя людини. Тому розробка цієї проблеми важлива не лише в теоретичному, але й у практичному плані, зокрема для виконання завдань реабілітації, ранньої діагностики та психокорекції подібних розладів, із метою забезпечення психологічного й психічного здоров'я людини, а також для розвитку особистісної та професійної самореалізації.

Аналіз досліджень заявленої проблематики. В останні десятиліття у вітчизняній психології сформувалося нове методологічне розуміння буття людини, що полягає в суб'єктно-середовищному підході до розгляду особистості, що дає змогу підійти до практичного вивчення особистості як психопросторового явища, котре характеризується певною структурою й володіє низкою властивостей i якостей. Ключовими конструктами в рамках цього підходу є поняття психологічного простору та психологічної суверенності особистості. С. К. Нартова-Бочавер указує, що психологічний простір, його виміри, кордони і їх стійкість можна розглядати і як компоненти структури особистості, і як характеристики основних аспектів іiі функціонування в соціумі, і як складники самосвідомості особистості (НартоваБочавер, 2008).

Проблема психологічного простору особистості та суверенності як характеристики психологічного простору має глибоке коріння як у вітчизняній, так і в зарубіжній психології. У сучасних психологопедагогічних науках категорія «простір» використовується в декількох смислових аспектах: як основна загальна форма існування руху матерії, як умова його буття і як форма просторово-часового існування й розвитку людини (Головаха \& Кроник, 2008).

На передумови до вивчення психологічного простору особистості можна натрапити в класичних теоріях особистості. Вільям Джеймс підкреслював важливість існування меж між особистістю й середовищем, стверджуючи, що людина постійно взаємодіє із середовищем, але не зливається 3 ним (Джеймс, 2016). Курт Левін розглядає поняття 
саме «життєвого простору», у зміст якого включив не лише психологічні явища (мотиви, цілі, когнітивні схеми), а й фізичні, економічні, правові та інші явища навколишнього світу, які також мають значний вплив на індивіда. На думку вченого, життєвий простір динамічний і може змінюватися залежно від ситуації та в онтогенезі (Левін, 2016).

Психологічний простір уключає комплекс фізичних, соціальних i суто психологічних явищ, iз якими людина себе ототожнює (територію, особисті предмети, соціальні прихильності, установки). Ці явища стають значущими в контексті психологічної ситуації, набуваючи для суб’єкта особистісного сенсу, та починають охоронятися всіма доступними йому фізичними й психологічними засобами (Коширець, 2016).

Психологічний простір має такі властивості: а) людина сприймає його як своє, присвоєне або створене нею самою, і тому має вартість; б) людина має можливість контролювати й захищати все, що міститься та виникає всередині простору, реалізуючи своє почуття авторства; в) простір існує природно й не рефлексує без виникнення проблемних ситуацій, він «прозорий» і тому з труднощами піддається позитивному опису; г) найважливішою характеристикою психологічного простору $є$ цілісність його кордонів. Емпірично С. К. Нартовою-Бочавер виокремлено й теоретично обгрунтовано шість вимірів психологічного простору особистості, які i являють собою канали взаємодії людини зі світом або, інакше кажучи, різні онтологічні мови, котрі відповідають різним потребам людини. Ось ці виміри: I - власне тіло, II - територія, III - особисті речі (артефакти), IV - часовий режим, V - соціальні зв’язки і VI - смаки (цінності). Усі ці виміри виконують необхідні для самозбереження й самоствердження функції (Нартова-Бочавер, 2008).

Особистісна суверенність заснована на узагальненому досвіді успішної автономної поведінки. Вона проявляється в переживанні автентичності власного буття (упевненості людини в тому, що вона вчиняє відповідно до власних бажань і переконань), у відчутті своєї доречності в просторово-часових та ціннісних обставинах власного життя. Протилежна суверенності характеристика позначається як депривація, що проявляється в переживанні підпорядкованості, відчуженості, фрагментарності власного життя й характеризується труднощами в пошуку об’ єктів середовища, із якими людина себе ідентифікує. 
За неможливості знайти психологічну суверенність простежуємо регресії, пов’язані з ригідною фіксацією однієї або декількох мов середовищного самовираження, що проявляється в психосоматичних розладах, територіальній експансії в поведінці, фетишизмі, ритуалізації й надконтролі над тимчасовими характеристиками поведінки, міжособистісних патологіях, сугестивності або схильності до впровадження «надцінних» ідей.

Ключове місце у феноменології психологічного простору займає стан його меж (кордонів) - фізичних і психологічних маркерів, які відділяють область особистого контролю та приватності однієї людини від такої галузі іншої. Дженей та Беррі Уайнхолд описують психологічні кордони як структуру, котра не дає змоги людям утручатися в простір один одного; як межу, яка розділяє сусідні ділянки, психологічні межі, які диференціюють «ваше» й «моє». Люди вчаться створювати свої кордони, спілкуючись із тими особами, у яких $\epsilon$ власні межі. У сім'ях із визначеними межами діти чітко розрізняють моє/не моє (Уайнхолд, 2015).

Більшість науковців виокремлюють такі види психологічних кордонів:

- фізичні кордони - можливість володіти власним тілом та майном. Вони визначають, наскільки у фізичному плані люди можуть буди близькими один 3 одним, сприяють формуванню відповідальності за власний організм. Особи, позбавлені меж, намагаються створювати «броню», захищаючи свої тіла від потенційного вторгнення в їхній особистісний простір, а саме вдаються до постійних заходів захисту (нарощують великі м'язи, страждають від ожиріння);

- емоційні кордони, що відображають почуття людей, які ставляться один до одного на рівні відчуттів. Правильні емоційні кордони встановлюють відмінність між власними почуттями та почуттями інших;

- ментальні кордони - ті, що визначають те, як люди сприймають світ. Вони дають змогу зрозуміти наші цінності, переконання, думки, бажання й потреби так, щоб ми могли відокремити свої погляди й відчуття від поглядів і відчуттів інших людей;

- духовні кордони дають змогу відчути вищі, більш довершені людські аспекти, допомагають розвинути стійкість духовного об'єкта та любити себе безумовно. Порушення духовних меж часто сприймають як навіювання страху й залякування. 
У психологічному аспекті для дорослої людини внутрішня зона безпеки - це можливість бути автентичною, розслабитися, не наслідувати нав'язливі стереотипи, не боятися зовнішніх оцінок. Та чимало людей навіть наодинці із собою не відчувають себе в безпеці, а натомість переживають напруженість і тривогу, настороженість, не кажучи вже про те, щоб хоч на деякий час відкинути стереотипи, оскільки вони є міцними орієнтирами, захистом від страху перед невідомим і новим (Figley, 1985).

Особистий психологічний простір дає змогу людині відокремитися, відмежуватися від світу предметів, соціальних і психологічних зв'язків як фону, середовища їі життєдіяльності. Залежно від сприйняття навколишнього світу як чужого або спорідненого, діяльність людини може набувати агресивного чи кооперативного характеру.

Стан і збереження психологічного простору, цілісність його кордонів визначають та відображають стан психічного здоров'я індивіда. Порушення кордонів психологічного простору можуть бути проявом i водночас причиною різних форм психічних порушень. У ролі важливих складових частин особистості для оцінки іiі психологічного стану можна розглядати сформованість вимірювань психологічного простору й стан психологічних меж, їхню стійкість.

Потрібно зазначити, що особистісний простір як інтегроване психологічне утворення особистості, забезпечує іiі недоторканість, збереження ідентичності, можливість самопрезентації, захист від маніпулятивного та інших негативних впливів із боку інших осіб. Тому можна констатувати, що порушення суверенності психологічного простору особистості можуть виявлятися як насильство над тілом, вторгнення на чужу особисту територію, використання речей без дозволу власника, а це, зі свого боку, призводить до реорганізації структурних елементів особистісного простору людини (Коширець, 2017).

В останні роки 3'явилося багато робіт стосовно феноменології психологічної суверенності; більшість із них відкриває зв'язок суверенності й різних аспектів психологічного та соціального благополуччя. Отримано непрямі дані, що свідчать про те, що ставлення людини до інших також можуть бути опосередковані рівнем іiі суверенності.

Тим часом відповідно до визначень суверенності як балансу між своїми потребами й потребами інших людей або міцності особистіс- 
них кордонів можна акцентувати розуміння суверенності як не тільки особистісного, а й міжособистісного феномену, адже кордони відокремлюють простір людини не від абстрактного світу взагалі, а від конкретних світів окремих людей, котрі можуть упроваджуватися самі або відчувати впровадження з боку інших.

Суверенність - це соціально адаптивна якість, що з'являється внаслідок узагальнення повсякденних ситуацій дитинства, у яких суб'єкт або успішно захищав свої особистісні межі, або зазнавав невдачі, але це завжди відбувалося в соціальному контексті. Справді, якщо помірна суверенність дає людині відчуття безпеки, то можна очікувати більшої діалогічності, толерантності, гуманності у відносинах із людьми. Проте досвід депривації стимулює превентивну або захисну агресивність, робить людину особливо чутливою до розрізнення своїх і чужих, тобто не толерантною (McFall M. E. \& Mackay, 1992).

Мета дослідження - теоретичне обгрунтування поняття особистісного простору військовослужбовців з ознаками ПТСР та емпіричне дослідження його психологічних особливостей.

У межах дослідження розглянуто особливості організації особистісного простору військовослужбовців, які мають ознаки посттравматичного стресового розладу. У військових 3 ознаками ПТСР спостерігаємо дезадаптованість та внутрішню напруженість, часто проявляються замкнутість, підвищення тривожності. У стосунках із людьми військовослужбовці із ПТСР $є$ прямолінійними й скептичними, важко йдуть на компроміс. За першої можливості уникнути розмови вони закриваються в собі, не діляться почуттями. Через постійні переживання й страх дають волю почуттям у складних ситуаціях, стають більш поступливими. Зменшення самоконтролю, спонтанність у поведінці, недотримання загальноприйнятих правил призводить до порушення соціальних зв'язків. Прийняття лише старих правил, норм і традицій, що були до стресової ситуації, ускладнює чи навіть унеможливлює їхню соціальну адаптацію (Александров, 2005).

Межі простору визначають ставлення до малого й великого соціуму - родини та друзів, соціальної групи, етносу, людства. Сприйняття соціуму як свого сприяє вияву конструктивних тенденцій, які проводять людину через прозорі для неї соціальні кордони, формується почуття спільності із широким колом людей. Якщо ж соціум відчувається як чужий, ці межі можуть блокуватися, обмежуючи поле 
самоактуалізації особистості виникненням ксенофобії різного масштабу - від життєвої агресивності до нетерпимості до соціально-етнічних груп. Міра переживання свого й чужого визначає здатність особистості до діалогу та спільної творчості в будь-яких сферах життєдіяльності, у тому числі й у військовій справі (Bleich A., Koslowsky M., Dolev A., Lerer B., 1997).

Психологічний простір особистості можна співвіднести з основними проявами психічного: він переживається суб'єктом як збережений чи порушений, що виражається в почуттях спокою чи неспокою; усвідомлюється поблизу своїх кордонів і не усвідомлюється в тих областях, які останнім часом не піддавалися змінам; виражається в поведінці, направленій на об'єкти, значущі для внутрішнього світу.

Структура особистісного простору містить такі компоненти, як адаптаційний, мотиваційний та особистісно-поведінковий, структурна конфігурація яких визначає сферу повноцінного життєздійснення як внутрішнього локусу контролю соціальної діяльності суб'єкта. Кожен iз компонентів виконує свої специфічні функції: адаптаційний компонент - пристосувальну, контролюючу й захисну; мотиваційний - стабілізувальну, ідентифікаційну та інноваційну; особистісно-поведінковий - організуючу, комунікативну й акумулювальну.

Безумовно, у військових, а тим більше військовослужбовців, які проходили службу в зоні АТО, особистісний простір є ціннісним середовищем, що забезпечує можливість власної адекватної самореалізації.

С. К. Нартова-Бочавер, характеризуючи поняття «психологічний простір особистості», указувала на те, що стан кордонів власного психологічного світу значною мірою визначає ставлення людини до елементів середовища, тобто його світовідчуття в цілому. Залежно від того, чи сприймається навколишній світ як чужий або рідний, будується й власна діяльність людини в ньому (Нартова-Бочавер, 2008).

Так, кожна особистість прагне захистити власний психологічний простір від надмірного втручання з боку інших людей, що проявляється в активізації різних невербальних характеристик спілкування. Відтак можна стверджувати, що окремі виміри особистісного простору військових зазнають кардинальних змін, що стосується, зокрема, території, особистих речей, соціальних зв'язків, смаків, уподобань тощо. Така реорганізація життя військовослужбовців пов'язана насамперед із впливом стресових факторів на психічне здоров'я, зокрема 
пережитих травмувальних подій та їх індивідуальної значимості для людини (Calhoun, Beckham, Bosworth, 2002).

Психологічна суверенність залежить від об'єктивно-середовищних умов життя людини; пов'язана 3 інстинктом територіальності й слугує соціальною формою реалізації біологічних програм; підтримується різними формами активності суб'єкта та тому пов'язана 3 індивідуально-особистісними особливостями різних рівнів індивідуальності.

Суверенність проявляється в поведінці, що відповідає бажанням і переконанням суб'єкта; у переживанні безпеки власного психологічного простору й своєї доречності в актуальних просторово-часових обставинах буття. Протилежний полюс конструкту позначений як депривованість, маркується почуттям відстороненості від реальності, самовідчуженням, фрагментарністю власного життя й проблемами 3 вибором об’єктів самоідентифікації (Коширець, 2016).

Психологічна суверенність пов'язана із життєвою продуктивністю і являє собою умову й результат адаптованості, зрілості та продуктивності особистості. Рівень суверенності в цілому пов'язаний із позитивністю Я-концепції, переживанням осмисленості життя, орієнтацією на активні форми розв'язання проблем. Джерелом порушення особистісної ефективності часто буває пережитий досвід деприваційних впливів, але їх наслідки неоднозначні: вони можуть як призвести до розвитку високого рівня суверенності й агресивної поведінки, так і викликати абсолютно протилежну реакцію.

Ураховуючи вищесказане, що стосується військових, які пережили певні психотравмувальні події, можемо лише припускати, який рівень особистісної суверенності притаманний їм і як це впливає на їхнє життя. Усе залежить від індивідуально-особистісних особливостей. Зважаючи на неналежну підготовку військових до екстремальних умов, зробимо висновок, що посттравматичні стани є дуже важкими для людини, особливо якщо особа тривалий час перебувала в стані стресу або під впливом певних зовнішніх умов. Багато залежить від самої психіки військовослужбовця, його підготовки, як психологічної, так і фізичної. Так, у разі бойових дій посттравматичний стресовий розлад є хронічним та відстроченим. У військових спостерігаються симптоми ПТСР, навіть якщо вони не брали активної участі в бойових діях, а перебували в прифронтовій зоні. Тому, зважаючи на це, можемо говорити про те, що особистісний простір військовослужбовців 
зазнає певних змін, причому вони мають деструктивний характер (Kessler, 1995).

Обгрунтовуючи поняття «особистісний простір», ми визначили, що це ті значущі взаємини, без яких неможливо вижити; ті стосунки, котрі задають моральні орієнтири. Ця думка є актуальною в контексті вивчення психологічних особливостей військових, які мають ознаки ПТСР, адже їхні моральні цінності, їхній світогляд значно змінилися після проходження служби в АТО та внаслідок пережитих психотравмувальних подій. Розглянувши теоретичний аспект психологічних особливостей посттравматичного стресового розладу, ознаки й причини виникнення, можемо зробити висновок про те, що на сьогодні в умовах збройного конфлікту в Україні, ця тема є досить актуальною. Узагальнення досліджень є підставою для того, щоб констатувати у військовослужбовців з ознаками ПТСР такі психологічні особливості, які негативно позначаються на їхньому повсякденному житті, на процесах адаптації та ресоціалізації й на організації особистісного простору зокрема.

Виклад основного матеріалу дослідження 3 повним обгрунтуванням отриманих результатів. Вивчення особистісного простору військовослужбовців 3 ознаками ПТСР здійснювалося на базі лікувально-профілактичного закладу «Волинський обласний госпіталь для інвалідів війни» й консультативно-психологічного центру при кафедрі практичної та клінічної психології ВНУ імені Лесі Українки. Респонденти - військовослужбовці віком від 23 до 58 років, які проходили службу в зоні АТО. У дослідженні взяли участь 122 особи.

Аби дослідити взаємозв’язок вираженості симптомів ПТСР і рівня суверенності особистісного простору досліджуваних, ми використали такі психодіагностичні методики:

1. Методику «Суверенність психологічного простору» (НартоваБочавер, 2014);

2. Опитувальник пацієнта про стан здоров'я (Patient Health Questionnaire - PHQ-9);

3. Опитувальник для скринінгу посттравматичного стресового розладу;

4. Шкалу оцінки впливу травматичної події (Impact of Event Scale, IES-R).

У ході дослідження отримано такі результати.

За методикою «Суверенність психологічного простору» одержано такі показники: у 37,7 \% досліджуваних виявлено нормативний серед- 
ньостатистичний рівень (40-60 Т-балів) суверенності психологічного простору (СПП); у 3,3 \% респондентів - низькі показники (менше 40 Т-балів), що свідчить про низький рівень суверенності психологічного простору й $59 \%$ військових мають високі показники (понад 60 Т-балів), що вказує на наявність високої суверенності психологічного простору особистості.

За шкалою суверенності фізичного тіла (СФТ) 24,6 \% військовослужбовців продемонстрували нормативні показники, що констатується як відсутність спроб людини порушити ії соматичне благополуччя; 16,4 \% досліджуваних мають низькі показники, що вказує на низький рівень суверенності фізичного тіла, яка проявляється в переживанні дискомфорту, викликаного дотиками, запахами. У 59 \% респондентів виявлено високий рівень суверенності фізичного тіла. Це демонструє відсутність спроб людини порушити власне соматичне благополуччя.

За шкалою суверенності території (СТ), у 34,4% військових виявлено нормативні показники, що означає переживання безпеки фізичного простору, у якому він перебуває (особистої частини або власної кімнати); у 8,2 \% досліджуваних - низькі показники, що вказує на низький рівень суверенності території, який проявляється у відсутності простору внаслідок територіальних кордонів. У 57,4 \% осіб діагностовано наявність високої суверенності території, що свідчить про переживання безпеки фізичного простору.

За шкалою суверенності світу речей (СР) 40,1% досліджуваних продемонстрували нормативні, середньостатистичні показники, що передбачає повагу до особистого майна людини, розпоряджатися яким може лише вона; 12 військових (10 \%) - низькі показники, що свідчить про низьку суверенність світу речей - невизнання їхнього права мати особисті речі. Із високим рівнем суверенності світу речей виявлено 60 осіб (49\%).

За шкалою суверенності звичок (С3) у 44,3 \% досліджуваних виявлено нормативні показники, що підтверджує прийняття тимчасової форми організації життя людини; 9,8 \% - із низькими показниками, тобто мають низький рівень суверенності звичок - насильницькі спроби змінити комфортний для суб'єкта розпорядок. Високий рівень суверенності звичок показало 46 \% військовослужбовців, що свідчить про прийняття часової форми організації життя людини, відсутність насильницьких спроб змінити комфортний для суб'єкта розпорядок.

За шкалою суверенності соціальних зв'язків (СС) у 39,3 \% респондентів діагностовано нормативні показники, що виражають право 
мати друзів і знайомих, які можуть не схвалюватися близькими; у 8 \% - низькі показники, а отже, низький рівень суверенності соціальних зв'язків - контроль над соціальним життям людини. Із високою суверенністю соціальних зв'язків виявлено 52,5 \% військових. Це вказує на визнання права особистості мати друзів і знайомих, які можуть не схвалюватися близькими.

За шкалою суверенності цінностей (СЦ) 57,3 \% опитаних показали середньостатистичну норму, що є свідченням свободи смаків та світогляду 4,9 \% осіб - низький рівень суверенності цінностей - насильницьке прийняття неблизьких цінностей. Високі показники за цією шкалою діагностовано в 37,7 \% військовослужбовців.

Результати дослідження психологічного простору за методикою С. К. Нартової-Бочавер подано нижче у вигляді діаграми.

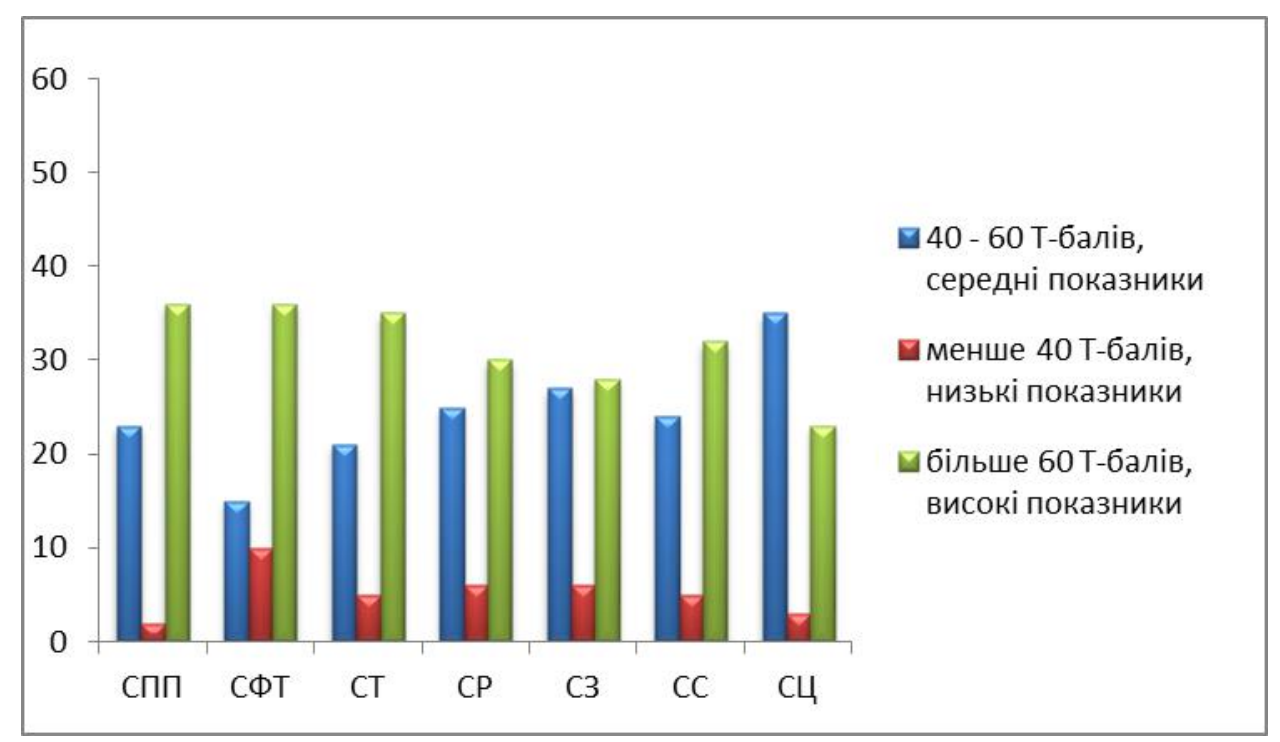

Рис. 1. Діаграма результатів дослідження за методикою «Суверенність психологічного простору»

Отже, можна підсумувати: значна кількість військовослужбовців має високі показники суверенності за всіма шкалами. Водночас серед досліджуваних $є$ такі, які мають середні та низькі дані рівня суверенності, що особливо важливо в контексті нашого психологічного дослідження.

За методикою «Опитувальник пацієнта про стан здоров'я (Patient Health Questionnaire - (PHQ)-9» отримано такі результати.

У $19,7 \%$ респондентів виявлено наявність депресивного стану. Простежено, що 14,8 \% осіб мають ознаки субклінічної або легкої депресії, яка супроводжується пригніченим настроєм, мінливим самопочуттям та вираженою втомою. 
4,9 \% досліджуваних перебувають у стані депресії помірної тяжкості. Помірна депресія характеризується нездатністю людини жити звичайним життям, наявне повне апатичне ставлення до подій, небажання боротись із ситуацією. Відчуваються роздратування, страх та тривога, утрата інтересу до праці, яка раніше приносила задоволення. Водночас виявлено, що 68,9 \% військових не мають схильності до депресії.

Отримані результати представлено на рис. 2.

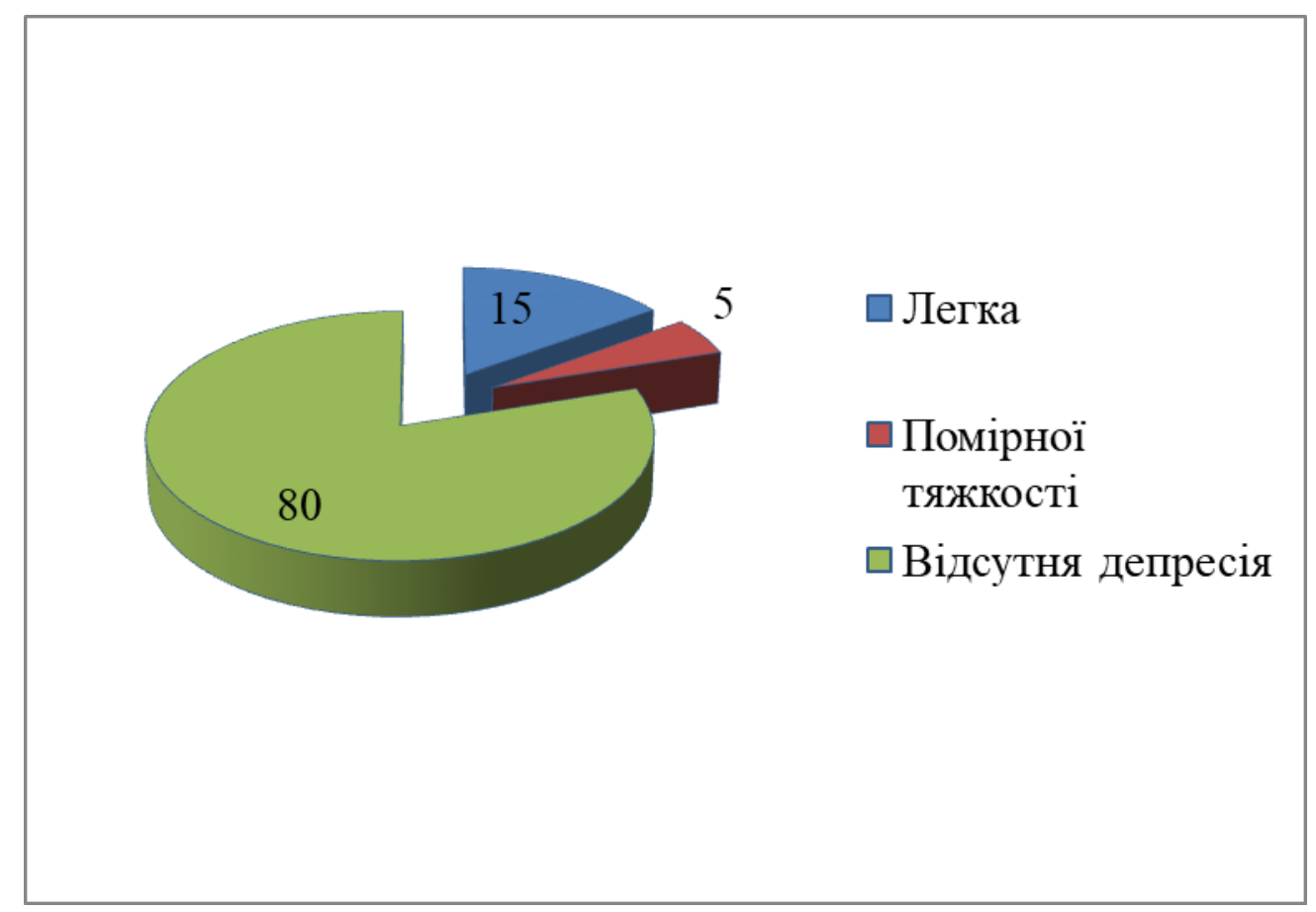

Рис. 2. Розподіл показників діагностованих за методикою «Опитувальник пацієнта про стан здоров'я Patient Health Questionnaire (PHQ)-9», \%

Отже, потрібно підсумувати, що більшість опитаних не мають ознак депресії, що свідчить про задовільний психічний стан досліджуваних, у 14,8 \% діагностовано легку депресію. Однак 4,9 \% військовослужбовців мають ознаки депресії помірної тяжкості, яка потребує психологічної допомоги 3 метою попередження складнішої форми депресивного розладу.

За методикою «Опитувальник для скринінгу посттравматичного стресового розладу» отримано такі результати: 59 \% військовослужбовців не мають жодних ознак посттравматичного стресового розладу, у $37,7 \%$ осіб є ймовірність ПТСР і 3,3 \% мають яскраво виражений ПТСР.

Результати дослідження ймовірності ПТСР у військових відображено нижче на рис. 3. 


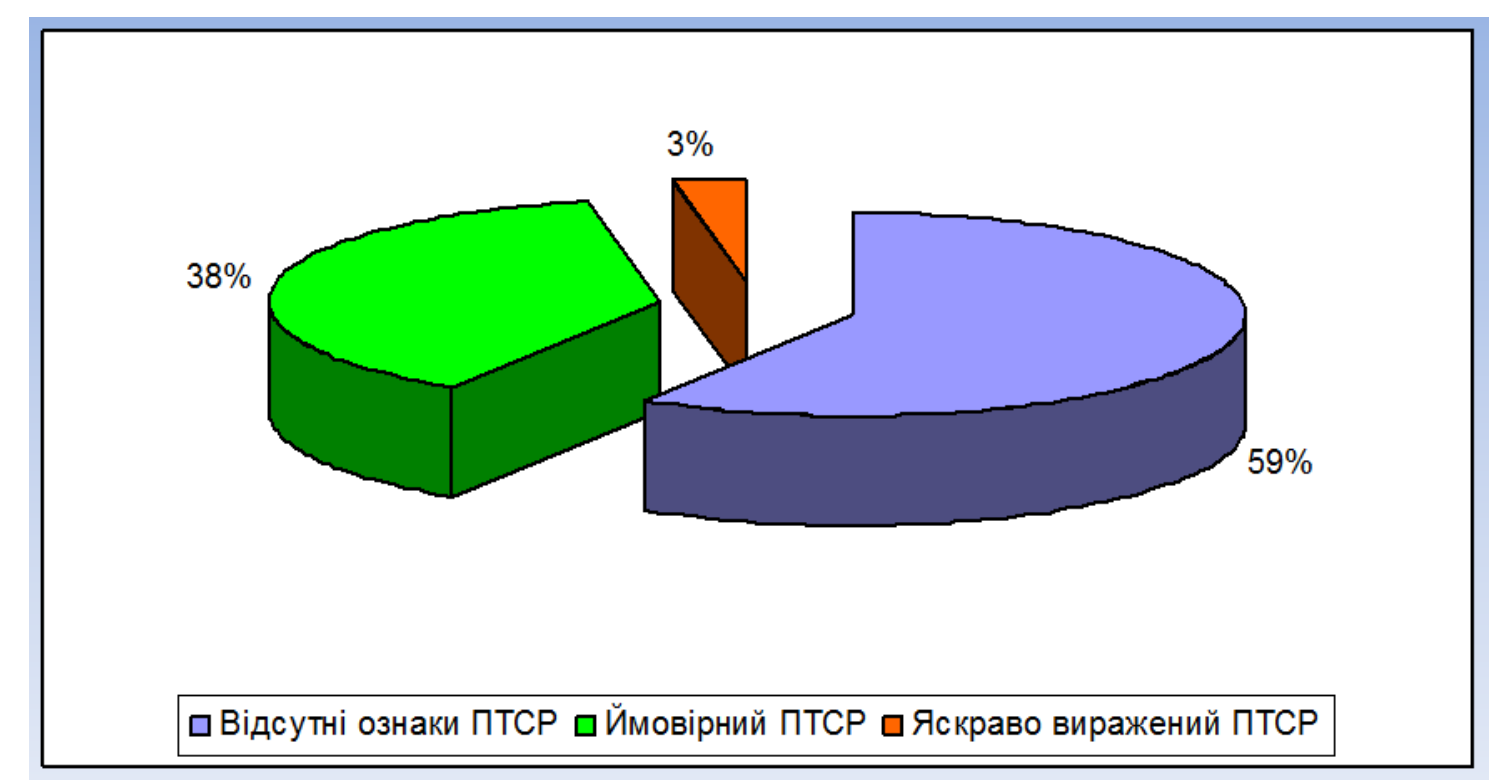

Рис. 3. Діаграма результатів дослідження за методикою «Опитувальник для скринінгу посттравматичного стресового розладу»

Перші симптоми посттравматичного розладу більше схожі на звичайну депресію: нав'язливі яскраві спогади, що часто повторюються в снах, постійне відчуття тривоги, дратівливість, підвищена чутливість до інших подій, які нагадують пережитий стрес, спалахи гніву, зниження концентрації уваги, а також почастішання серцебиття, підвищення артеріального тиску, головний біль.

Військові, які страждають на ПТСР, можуть постійно перебувати в стані підвищеної боєготовності, дуже швидко відчувають нервове збудження. Вони намагаються уникати речей, які можуть нагадувати про воєнні події. А спогади можуть повернутися будь-коли. Тоді військовий відчуватиме той самий страх і жах, який він відчував безпосередньо на фронті. Коли в людини немає можливості розрядити внутрішнє напруження, iї тіло та психіка знаходять спосіб якось пристосуватися до цієї напруги (Calhoun, Beckham, Bosworth, 2002).

Імовірність того, що у військового розвинеться ПТСР, залежить від багатьох факторів, як-от: наскільки сильною була психологічна травма; чи був він поранений; інтенсивність реакції на травму; чи був хтось із близьких поранений або ж загинув; наскільки сильною була небезпека для його власного життя; наскільки сильно він відчув утрату контролю над ситуацією; яку допомогу й підтримку отримав після травмувальної події. Наслідки ПТСР призводять до зміни особистості, соціальної та професійної дезінтеграції, алкогольної й наркотичної залежності, суїцидів. А відсутність спеціальних медико-психологічних 
заходів для відновлення психологічної реабілітації - до хронічного перебігу психічних розладів.

За методикою «Шкала оцінки впливу травматичної події» отримано такі результати.

Симптоми інтрузії виявлено у 26,2 \% військовослужбовців. Інтрузія - це повторне переживання події, що супроводжується образами, думками, відчуттями. Можливі повторювані сни про пережитий «кошмар наяву», що викликає значне занепокоєння. Нерідко бувають такі дії або відчуття, ніби травматична подія трапилася знову (уключаючи відчуття відтворення пережитого, ілюзії, галюцинації тощо). Можливий сильний психологічний дистрес під впливом зовнішніх або внутрішніх подразників, які символізують або нагадують який-небудь аспект травматичної події, що найчастіше призводить до зайвої реактивності людини.

Симптоми уникання наявні в 16,3 \% осіб. Уникнення припускає постійне уникання стимулів, пов'язаних із травмою, й загальне заціпеніння, що було відсутнє до травми, про що можуть свідчити щонайменше три симптоми:

- спроби уникнути думок, відчуттів або розмов, пов'язаних із травмою;

- небажаність дій, місць або людей, які нагадують про те, що сталося;

- нездатність або небажання орієнтуватися на тривалу життєву перспективу (маються на увазі кар'єра, одруження, можливість мати дітей тощо).

Симптоми гіперактивності мають 13,1\%. Гіперактивність - стійкі прояви підвищеного збудження (що були відсутні раніше), про що можуть свідчити труднощі під час засинання або порушення тривалості сну, неконтрольовані вибухи гніву, настороженість, посилена реакція на страхи та інше.

Результати дослідження за шкалою оцінки впливу травматичної події у військових подано нижче на рис. 4.

Посттравматичний стресовий розлад може спричинити у військовослужбовців, зазвичай, такі небажані наслідки, як інтрузія, уникнення й гіперактивність. Як показали результати застосування методики, понад 10 \% військових мають вищевказані симптоми.

Висновки та перспективи. У військовослужбовців як особливої категорії людей є деякі особливості організації особистого простору, а 
особливо в тих, які мають ознаки посттравматичного стресового розладу. Для них властиві дезадаптованість та внутрішня напруженість, часто проявляються замкненість, підвищення тривожності. У стосунках із людьми військовослужбовці з ПТСР є прямолінійними та скептичними, важко йдуть на компроміс.

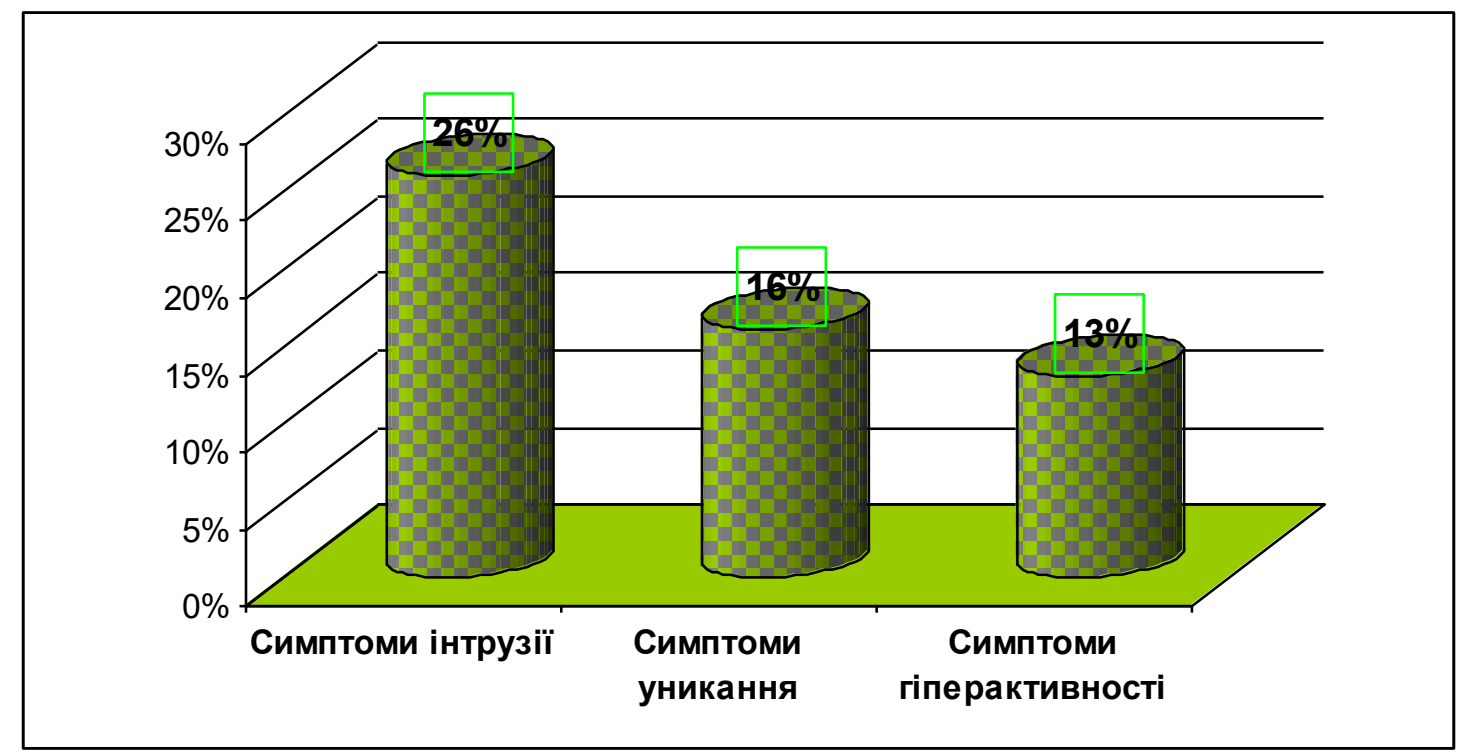

Рис. 4. Діаграма результатів дослідження за методикою «Шкала оцінки впливу травматичної подї̈»

Кожна особистість прагне захистити власний психологічний простір від надмірного втручання з боку інших людей. Безумовно, у військових, які проходили службу в зоні АТО, особистісний простір є скоріше ціннісним середовищем, що забезпечує можливість адекватних власній природі самопроявів.

Відтак, зважаючи на певні особливості військовослужбовців, які мають посттравматичний розлад, можемо стверджувати, що окремі виміри особистого простору військових зазнають кардинальних змін, котрі стосуються, зокрема, території, особистих речей, соціальних зв'язків, смаків, уподобань тощо. Така реорганізація простору військовослужбовців пов'язана насамперед із впливом стресових факторів на психічне здоров’я, а саме пережиті травмувальні події та їх індивідуальна значимість для людини.

Узагальнення досліджень дає підставу констатувати у військовослужбовців 3 ознаками ПТСР такі психологічні особливості, які негативно позначаються на їхньому повсякденному житті, на процесах адаптації та ресоціалізації й на організації їхнього особистісного 
простору зокрема. За результатами емпіричного дослідження виявлено, що в 37,7 \% досліджуваних виявлено нормативні, середньостатистичні показники суверенності психологічного простору (СПП), що $є$ ознакою невизначеної позиції щодо встановлення суверенності військовими свого психологічного простору.

Доведено, що для 59 \% військових характерні високі показники, що вказує на наявність високої суверенності психологічного простору особистості. Це означає, що вони окреслили свій життєвий простір як найбільш значущу (близьку, улюблену, цікаву) для них частину життєвого світу, яка суб'єктивно визначає найважливішу сторону їхньої життєдіяльності. Така позиція найчастіше відображається в характеристиках особистості, пов'язаних із її автономністю, самостійністю та стійкістю. І лише в 3,3 \% військовослужбовців спостерігаємо низький рівень суверенності психологічного простору, що засвідчує вияв у них ознак депривованості, яка виявляється в переживанні відчуження й фрагментарності власного життя, що характеризується суттєвими ускладненнями в пошуку об'єкта ідентифікації.

Дослідження показало, що у військових із низьким рівнем суверенності психологічного простору яскраво виражені показники схильності до посттравматичного стресового розладу. Тобто низька суверенність простору, тіла, соціальних зв'язків, речей, цінностей впливає на вірогідність виникнення у військовослужбовців ознак ПТСР.

Аналогічний взаємозв'язок виявлено між рівнем суверенності та наявністю тенденції до ПТСР: ті військовослужбовці АТО, які мають високий рівень суверенності психологічного простору, не мають виражених ознак посттравматичного стресового розладу.

Перспективи подальших розвідок у цьому напрямі вбачаємо в розробці психопрофілактичних та психореабілітаційних програм 3 урахуванням основних факторів й умов формування ПТСР: особливостей самої травматичної події, наявності негативних «професійних» чинників, соціально-демографічних і соціально-економічних характеристик, анамнестичних даних, соціально-психологічних та індивідуально-психологічних особливостей військовослужбовців.

\section{Література}

1. Александров, Е. О. (2005). Интегративная психотерапия посттравматического стрессового расстройства. Новосибирск: Сибпринт.

2. Головаха, Е. И., Кроник, А. А. (2008). Психологическое время личности. Москва: Смысл. 
3. Джеймс, У. (2016). Психология. Москва: Рипол Классик.

4. Коширець, В. В. (2017). Особливості надання психологічної допомоги особам з ПТСР. Психологія: реальність і перспективи, 8, 128-133.

5. Коширець, В. В. (2016). Суверенність психологічного простору молодої людини в контексті становлення іiі особистісної зрілості. Психологічні перспективи, 28, 151-164.

6. Левин, К. (2016). Теория поля в социальных науках. Москва: Академический проект.

7. Матяш, М. М., Худенко, Л. І. (2014). Український синдром: особливості посттравматичного стресового розладу в учасників антитерористичної операції. Украӥнський медичний часопис. Актуальні питання клінічної практики, 6, $151-164$.

8. Нартова-Бочавер, С. К. (2014). Новая версия опросника «Суверенность психологического пространства-2010». Психологический журнал, 35 (3), $105-119$.

9. Нартова-Бочавер, С. К. (2008). Человек суверенный: психологическое исследование субъекта в его бытии. Санкт-Петербург: Питер.

10. Уайнхолд, Берри, Уайнхолд, Дженей. (2019). Освобождение от созависимости. Москва: Класс.

11. Bleich, A., Koslowsky, M., Dolev, A., Lerer, B. (1997). Posttraumatic stress disorder and depression: an analysis of comorbidity. Brit. J. Psychiatry, 170, 479-482.

12. Calhoun, P. S., Beckham, J. C., Bosworth, H. B. (2002). Caregiver burden and psychological distress in partners of veterans with chronic posttraumatic stress disorder. Journal Trauma Stress, 15 (3), 205-212.

13. Figley, C. R. (1985). Traumatic stress: the role of the family and social support system. Trauma and Its Wake, Vol. II: The Study and Treatment of PostTraumatic Stress Disorder. New York: Brunner/Mazel, 39-54.

14. Kessler, R., Sonnega, A., Bromet, E. (1995). Posttraumatic Stress Disorder in the National Comorbidity Survey. Arch. Gen. Psychiatry, 52, 1048-1060.

15. McFall, M. E., Mackay, P. W., Donovan, D. M. (1992). Combat-related posttraumatic stress disorder and severity of substance abuse in Vietnam veterans. J. Stud. Alcohol, 53 (4), 357-363.

\section{References}

1. Aleksandrov, E. O. (2005). Integrativnaya psihoterapiya posttravmaticheskogo stressovogo rasstroystva [Integrative psychotherapy of posttraumatic stress disorder]. Novosibirsk: Sibprint (in Russian).

2. Golovaha, E. I., Kronik, A. A. (2008). Psihologicheskoe vremya lichnosti [Psychological time of a pesonality]. Moskva: Smyisl (in Russian).

3. Dzheyms, Uilyam (2016). Psihologiya [Psychology]. Moskva: Ripol Klassik (in Russian).

4. Koshyrets, V. V. (2017). Osoblyvosti nadannia psykholohichnoi dopomohy osobam z PTSR [Peculiarities of providing psychological assistance to persons with 
PTSD]. Psykholohiia: realnist i perspektyvy: zbirnyk naukovykh prats Rivnenskoho humanitarnoho universytetu, 8, 128-133 (in Ukrainian).

5. Koshyrets, V. V. (2016). Suverennist psykholohichnoho prostoru molodoi liudyny $\mathrm{v}$ konteksti stanovlennia yii osobystisnoi zrilosti [Psychological space sovereignty of a young person in the context of personal maturity becoming]. Psykholohichni perspektyvy: $z b$. nauk. pr. Skhidnoievropeiskoho natsionalnoho universytetu imeni Lesi Ukrainky, 28, 151-164 (in Ukrainian).

6. Levin, Kurt (2016). Teoriya polya v sotsialnyih naukah [Field theory in social sciences]. Moskva: Akademicheskiy proekt, 316 p. (in Russian).

7. Matiash, M. M. (2014). Ukrainskyi syndrom: osoblyvosti posttravmatychnoho stresovoho rozladu v uchasnykiv antyterorystychnoi operatsii [Ukrainian syndrome: peculiarities of posttraumatic stress disorder among the anti-terrorist operation participants]. Ukrainskyi medychnyi chasopys. Aktualni pytannia klinichnoi praktyky, 6, 124-127 (in Ukrainian).

8. Nartova-Bochaver, S. K. (2014). Novaya versiya oprosnika «Suverennost psihologicheskogo prostranstva-2010» [New version of «Psychological space sovereignty-2010» questionnaire]. Psihologicheskiy zhurnal, 35, 3, 105-119 (in Russian).

9. Nartova-Bochaver, S. K. (2008). Chelovek suverennyiy: psihologicheskoe issledovanie sub'ekta $\mathrm{v}$ ego byitii [The sovereign man: psychological study of the subject in his being]. Sankt-Peterburg: Piter (in Russian).

10. Uaynhold, Berri, Uaynhold, Dzheney (2019). Osvobozhdenie ot sozavisimosti [Release from codependency]. Moskva: Klass (in Russian).

11. Bleich, A., Koslowsky, M., Dolev, A., Lerer, B. (1997). Posttraumatic stress disorder and depression: an analysis of comorbidity. Brit. J. Psychiatry, 170, 479-482.

12. Calhoun, P. S., Beckham, J. C., Bosworth, H. B. (2002). Caregiver burden and psychological distress in partners of veterans with chronic posttraumatic stress disorder. J. Trauma Stress, 15, 3, 205-212.

13. Figley, C. R. (1985). Traumatic stress: the role of the family and social support system. Trauma and Its Wake, Vol. II: The Study and Treatment of PosttTraumatic Stress Disorder. New York: Brunner/Mazel, 1985, 39-54.

14. Kessler, R. C. (1995). Posttraumatic Stress Disorder in the National Comorbidity Survey. Arch. Gen. Psychiatry, 52, 1048-1060.

15. McFall, M. E., Mackay, P. W., Donovan, D. M. (1992). Combat-related posttraumatic stress disorder and severity of substance abuse in Vietnam veterans. J. Stud. Alcohol, 53, 4, 357-363.

Received: 02.09.2020

Accepted: 17.10.2020 